\title{
АКТУАЛЬНІ ПРОБЛЕМИ КРИМІНАЛЬНОГО ПРАВА ТА ПРОЦЕСУ
}

УДК 343.2

DOI https://doi.org/10.51989/NUL.2021.4.26

\section{СУБ'ЄКТИВНІ ОЗНАКИ КРИМІНАЛЬНИХ ПРАВОПОРУШЕНЬ НЕПОВНОЛIТНIХ ОСІБ}

\section{Кравчук Степан Йосипович,}

кандидат юридичних наук, доцент, доцент кафедри права

Хмельницького національного університету

У статті схарактеризовані суб'єктивні ознаки кримінальних правопорушень неповнолітніх, визначаються особливості суб'єкта й суб'єктивної сторони, встановлюється взаємозв'язок мотивів кримінального правопорушення та особистості неповнолітнього.

Натепер важливою проблемою залишається здійснення судочинства щодо неповнолітніх. Науковці й практики обґрунтовують необхідність особливого вирішення справ за участю неповнолітніх, оскільки вони не в змозі однозначно визначити доцільність, мету, завдання, структуру системи особливого розв'язання проблеми удосконалення норм законодавства щодо кримінальної відповідальності неповнолітніх.

Для встановлення кримінальної відповідальності важливі суб'єктивні ознаки будь-якого злочину неповнолітнього, що характеризують суб'єкта й суб'єктивну сторону кримінального правопорушення. Вагомим аспектом цієї проблеми $\epsilon$ визначення необхідності настання відповідного віку кримінальної відповідальності, оскільки суб'єктом кримінального правопорушення має бути осудна особа. Осудність має визначатися з урахуванням двох критеріїв: юридичного (факту вчинення кримінального правопорушення психічно здоровою особою, здатною повною мірою усвідомлювати свої дії (а також їх наслідки) і керувати ними під час вчинення злочину) і психологічного (стану свідомості особи, ії здатності до усвідомленої діяльності).

Важливим елементом складу будь-якого кримінального правопорушення є суб'єктивна сторона. Встановлення об'єкта, об'єктивної сторони, суб'єкта створює необхідні умови для визначення суб'єктивної сторони складу кримінального правопорушення, якою є внутрішній прояв суспільно небезпечного діяння, що дає уяву про психічні процеси, які відбуваються у свідомості винної особи під час вчинення нею правопорушення.

Необхідною умовою законності й обгрунтованості застосування кримінально-правових засобів до неповнолітньої особи, яка скоїла кримінальне правопорушення, є встановлення відповідних ознак суб'єктивної сторони. Суб'єктивна сторона містить дві групи юридичних ознак: обов'язкові й факультативні. До обов'язкових ознак належить вина, до факультативних - мотив, мета й емоційний стан.

Під час вивчення суб'єктивної сторони втягнення неповнолітніх у кримінальне правопорушення важливе значення для кваліфікації діяння дорослого має мотив і ціль. Мотив кримінального правопорушення - це спонукання до його вчинення. Під ціллю розуміється той подумки передбачуваний результат, до досягнення якого прагне суб'єкт. Мотив і ціль взаємопов'язані між собою, і не тільки взаємопов'язані, але й визначають один одного й за своїм змістом часом збігаються. Тобто мотиви кримінального діяння тісно пов'язані з особистістю як внутрішньою єдиною та складною системою стану, якостей і процесів. Тому вивчення взаємозв'язку мотивів кримінального правопорушення та особистості неповнолітнього $є$ однією з важливих задач соціально-психологічних і кримінологічних досліджень.

Ключові слова: неповнолітні, кримінальні правопорушення, кримінальна відповідальність, елементи суб'єктивної сторони кримінального правопорушення, мотиви правопорушення. 


\section{Kravchuk Stepan. Subjective elements of juvenile criminal offences}

The subjective features of the juveniles criminal offences are characterized in the article, both the features of the subject and the mental element are defined, the correlation of the criminal offence motives and the offender's personality are determined.

Today, an important issue is still the administration of juvenile justice. Researchers and experts substantiate the need for special treatment of cases that involve juveniles, because they cannot be unambiguous in outlining the reasonability, purpose, task and structure of the system of special treatment for the issue of improving the legal standards of juvenile criminal liability.

To determine the criminal liability, important are the subjective features of any juvenile delinquency, which characterize the subject and the mental elements of a criminal offence. An important aspect of this issue is to outline the need for approaching the appropriate age of criminal liability, because only a person responsible for his / her actions (a criminally sane person) can be the subject of a criminal offence. Criminal sanity should be determined with due consideration of the following two criteria: legal (this criminal offence being committed by a mentally healthy person able to be conscious of his/her actions (and their consequences) in full and to control them during the crime) and psychological (state of the person's consciousness, his/her ability to commit conscious actions).

An important element in the body of any criminal offence is a mental element. Determination of an object, a physical element, a subject provides for the conditions required to determine the mental elements of a criminal offence that are an internal manifestation of a socially dangerous act, which gives the understanding of the mental processes that occur in the consciousness of the guilty person while he/she is committing an offence.

An integral condition of legitimacy and reasonability of applying criminal remedies to a juvenile who committed a criminal offence is to determine the specific features of mental elements. Mental elements involve two groups of legal features: mandatory and optional. Mandatory features include the guilt; optional features include a motive, a purpose and the emotional state.

In studying the mental elements of involvement of juveniles, a motive and a purpose are important to determine the adult's act. A motive of a criminal offence is the encouragement to commit such an offence. A purpose is the mentally anticipated result desired by the subject. A motive and a purpose correlate - and not only correlate, but also define each other and sometimes coincide in their essence. In other words, the criminal offence motives are closely related with the person as a single and complex internal system of the state, qualities and processes. That is why, to study the correlation of the criminal offence motives and the offender's personality is one of the important tasks in the social and psychological research and criminological studies.

Key words: juveniles, criminal offences, criminal liability, mental elements of a criminal offence, offence motives.

Неповнолітній як суб'єкт відповідальності постійно привертає до себе особливу увагу вчених і практиків. Це зумовлено не лише тим, що неповнолітні завжди визнавалися злочинцями особливого роду, а й тим, що в наш час неповнолітні - одна з найбільш кримінально уражених верств населення. Так, соціально-економічна криза в Україні, безробіття, невирішені завдання культурно-виховного характеру інтенсивно впливають на психологічне формування молодого покоління та їх адаптацію в суспільстві. Особливого значення набула проблема алкоголізму й наркоманії серед неповнолітніх. Тому проблема здійснення судочинства щодо неповнолітніх із кожним роком набуває все більшої актуальності: з одного боку, про це говорять громадські діячі, які займають активну позицію щодо захисту дитини, з іншого, - науковці й практики, які обґрунтовують необхідність особливого вирішення справ за участю неповнолітніх. Проте й дотепер вони не в змозі однозначно визначити доцільність, мету, завдання, структуру системи особливого розв'язання проблеми удосконалення норм законодавства щодо кримінальної відповідальності неповнолітніх. Очевидним $\epsilon$ те, що система кримінально-правового впливу на неповнолітніх правопорушників потребує компромісного вирішення. Адже тут входять між собою в колізію, з одного боку, інтереси суспільства, які потребують захисту, а з іншого, інтереси охорони молодого покоління, 
важливість яких для майбутнього кожної нації не викликає сумнівів.

Значний внесок натепер у розв'язання проблем удосконалення законодавчої системи щодо кримінальної відповідальності неповнолітніх зробили у своїх працях такі вчені як В.М. Бурдін, В.І. Мороз, С.В. Бородін, Н.А. Носкова, З.А. Астеміров, Г.С. Гаверов, Н.І. Гуковська, А.І. Долгова, І.О. Кобзар, Л.М. Кривоченко, Г.М. Міньковський, Е.Б. Мельнікова, В.Ф. Мороз, В.С. Орлов, Т.А. Гончар, А.А. Прімаченок, I.М. Сабіров, Н.К. Семернева, М.О. Скрябін, К.К. Сперанський, М.С. Таганцев, А.П. Тузов, О.І. Чернишев, О.П. Чугаєв, Я.М. Шевченко, А.Е. Якубов та інші.

На сьогодні викликає занепокоєння розповсюдженість серед неповнолітніх тяжких та зухвалих кримінальних правопорушень. Все більше суспільно небезпечні діяння неповнолітніх набувають форм жорстоких корисливо-насильницьких посягань. Велика кількість кримінальних правопорушень вчиняється у співучасті (як правило у формі співвиконавства). Майже їх половина вчиняється неповнолітніми у групі, що відповідає специфіці психології підлітків. Майже кожен третій злочин вчиняється ними разом з дорослими. Почастішала кримінальна «спеціалізація» підлітків. Вони вже скоюють злочини на замовлення, все частіше - із застосуванням зброї. У переважній більшості випадків неповнолітні злочинці - це особи із антисоціальною спрямованістю та схильністю до стійких стереотипів антисуспільної поведінки. Випадково вчиняють злочини лише одиниці з них. На фоні зростання злочинності серед неповнолітніх зростає і кількість суспільно небезпечних діянь, які вчиняються особами до досягнення віку кримінальної відповідальності [4, с. 50].

Для кримінальної відповідальності важливими $\epsilon$ визначення суб'єктивних ознак будь-якого злочину неповнолітнього, що характеризують суб'єкта та суб'єктивну сторону злочину. Науковці досліджували суб'єктивні ознаки кримінальних правопорушень, вчинених повнолітніми особами. Певною мірою вони досконало вивчали правові аспекти вчинення неповнолітніми кримінальних правопорушень. Разом із тим потребують досконалого вивчення суб'єктивні ознаки неповнолітнього, оскільки вчинення ними правопорушення мають соціально-психологічні особливість, Зокрема, важливою характеристикою $\epsilon$ сам суб'єкт такого кримінального правопорушення, а також суб'єктивна сторона. Тому дослідження таких ознак важливе для практичного застосування правоохоронними органами під час розслідування всіх кримінальних правопорушень, вчинених неповнолітніми, а також судовому розгляді відповідної категорії кримінальних справ що $€$ науковою новизною статті.

Як відмічалось вище, основною особливістю правової характеристика суб'єктивних ознак, їх практичне застосування у слідчій практиці $\epsilon$ сам суб'єкт вчинення правопорушення, тобто неповнолітня особа. Поряд з цим, важливим аспектом цієї проблеми $\epsilon$ визначення необхідності настання відповідного віку кримінальної відповідальності, оскільки суб'єктом злочинів має бути осудна особа. Відповідно до ч. 1 ст. 19 Кримінального кодексу (далі - КК) України осудною визнається особа, яка під час вчинення злочину могла усвідомлювати свої дії (бездіяльність) і керувати ними, з переконанням А.В. Савченка, ця ознака для суб'єкта злочину означає, що він: по-перше, має такий стан психіки людини, коли вона може нести відповідальність за вчинений злочин; по-друге, має відповідний рівень соціального розвитку, зумовлений віком [8, с. 94]. За таких умов варто погодитися з В.В. Ленєм, що осудність - це «психічний стан особи (рівень соціально-психологічного розвитку, психічне здоров'я, вік), здатної усвідомлювати й давати собі звіт про свої дії (бездіяльність), тобто розуміти їх суспільне значення та керувати ними, а також поєднана 3 цим спроможність нести за вчинений злочин кримінальну відповідальність і покарання» [4, с. 50].

Загалом під час вчинення цієї категорії злочинів осудність має визначатися з урахуванням двох критеріїв: юридичного (факту вчинення цього злочину психічно здоровою особою, здатною повною мірою усвідомлювати свої дії (а також їх наслідки) та керувати ними під час вчинення злочину) та психологічного (стану свідомості особи, ії здатності до усвідомленої діяльності, тобто: 
а) здатності особи повною мірою усвідомлювати фактичну сторону та суспільну небезпеку цього діяння (а отже й їх наслідків);

б) здатності керувати своїми діями . Суміжними для осудності $\epsilon$ поняття «неосудність» та «обмежена осудність».

I, якщо в разі неосудності на підставі ч. 2 ст. 19 КК України неповнолітній взагалі не повинен підлягати кримінальній відповідальності за кримінальне правопорушення, то в разі обмеженій осудності такий стан не звільняє ії від кримінальної відповідальності, проте враховується судом під час призначення покарання та може бути підставою для застосування примусових заходів медичного характеру [2]. У будь-якому випадку в разі виникнення сумнівів щодо психічного стану обвинуваченого (підсудного) неповнолітнього, слідчому (суду) необхідно призначити судово-психіатричну експертизу.

Важливим елементом складу будьякого кримінального правопорушення $\epsilon$ суб'єктивна сторона. Встановлення об'єкта, об'єктивної сторони та суб'єкта створює необхідні умови для визначення суб'єктивної сторони складу злочину. Саме з аналізу цих елементів починається розкриття та правове осмислення механізму реалізації помислів, почуттів особи, встановлення ії в конкретному вигляді. Кримінальному праву України притаманна суб'єктивна осудність. Вона протилежна об'єктивній, коли відповідальність особи залежить від наслідків, які фактично настали [3, с. 52-53]. У кримінальному праві суб'єктивна сторона - це внутрішній прояв суспільно небезпечного діяння, що дає уяву про психічні процеси, які відбуваються у свідомості винної неповнолітньої особи під час вчинення нею злочину [3, с. $114 ; 9$, с. $45 ; 8$, с. 101-102].

Необхідною умовою законності й обґрунтованості застосування кримінальноправових засобів до неповнолітньої особи, яка скоїла кримінальне правопорушення, $\epsilon$ встановлення відповідних ознак суб'єктивної сторони. Вирішення цього завдання дозволить розкрити сутність скоєних особою дій, спрямованих на вчинення злочинів із залученням неповнолітніх або щодо неповнолітніх та дати їм реальну правову та морально-політичну оцінку. За висно- вками Є.В. Фесенко, від правильного встановлення ознак суб'єктивної сторони безпосередньо залежать висновок про винність неповнолітньої особи у скоєному злочині, правильна кваліфікація ії̈ діяння та призначення відповідного покарання [10, с. 143].

Суб'єктивна сторона включає в себе дві групи юридичних ознак: обов'язкові та факультативні. До обов'язкових ознак відноситься вина, до факультативних мотив, мета та емоційний стан. Відповідно до ст. 23 КК України вина - це психічне ставлення особи до вчинюваної дії чи бездіяльності, передбаченої кримінальним законом, та її наслідків, виражене у формі умислу або необережності [3, с. 53]. Як зазначає А.А. Піонтковський, вчення про вину $є$ одним з основоположних елементів теорії кримінального права. Без вини не може бути кримінальної відповідальності. Правильне розуміння вини має велике значення у боротьбі зі злочинністю та зміцненні законності в державі [7, с. 301]. Вина неповнолітнього основна і обов'язкова ознака суб'єктивної сторони зло чину, хоча вона і не вичерпує їі. Під час конструювання як умисної, так і необережної форм вини, законодавець використовує лише два елементи психіки - інтелектуальний і вольовий [2]. Емоційний зміст психічних процесів неповнолітнього не враховується у кримінально-правовій характеристиці умислу й необережності (залишається за їхніми межами).

Крім того, суб'єктивна сторона має і соціально-політичне значення. Вона відбиває не тільки об'єктивну небезпечність втягнення неповнолітніх, але й визначається умовами суспільно-політичного життя. Для правильної кваліфікації злочинів необхідною умовою $\epsilon$ точне встановлення їх суб'єктивної сторони, зокрема змісту й спрямованості умислу.

Суб'єктивна сторона втягнення (схиляння) неповнолітніх у злочинну та іншу антисуспільну діяльність характеризується тільки прямим умислом. Тобто, дорослий, який втягує підлітка в таку діяльність, усвідомлює суспільно небезпечний характер свого діяння і бажає так діяти. Таким чином, необережність та непрямий умисел у таких злочинах виключається. 
У зв'язку з тим, що ст. 304 КК України відноситься до формальних складів злочинів, суспільно небезпечний результат органічно включається у дію. У таких випадках вчинення дій $\epsilon$ разом із тим і заподіянням результату. Тому, за висновками Ю.В. Орел, «<...> передбачення суспільно небезпечного результату повністю охоплює всю суспільно небезпечну ситуацію» [6, с. 57]. Шкідливі наслідки, незалежно від їх тяжкості, можуть бути поставлені особі лише в тому випадку, якщо вона діяла щодо них умисно або допускала їх з необережності.

Під час вивчення суб'єктивної сторони втягнення неповнолітніх важливе значення для кваліфікації діяння дорослого має мотив і ціль. Мотив злочину - це спонукання до вчинення злочину. Мотиви це усвідомлені потреби людини як дійсні, так і уявні, це внутрішнє спонукання особи до певної дії [5, с. 89]. Сутність мотиву полягає у тому, що він завжди пов'язаний з певними спонуканнями, які викликали у особи бажання, рішучість вчинити протиправне діяння. Це не просто спонукання до дій, а усвідомлене спонукання, зумовлене бажанням досягти певного результату, певної мети. Отже, мотив - це спонукальна причина поведінки людини. А чинником самого мотиву $\epsilon$ їі певні потреби, почуття, емоції.

Останньою факультативною ознакою суб'єктивної сторони злочину $є$ емоційний стан. Емоційний стан - це певний психічний стрес, У стані якого особа вчиняє злочин [4, с. 128]. Це емоції, які впливають на характер суспільної небезпеки діяння $[9$, c. 50]. Щодо емоційного стану як ознаки суб'єктивної сторони злочинів, вчинених із залученням неповнолітніх і щодо непов- нолітніх, то він, на наш погляд, не повинен впливати на їх кваліфікацію. Адже про нього безпосередньо не йдеться у їх складах, і тим більше, його наявність прямо не випливає зі змісту.

Під ціллю розуміється той подумки передбачуваний результат, до досягнення якого прагне суб'єкт. Мотив і ціль взаємопов'язані між собою, і не тільки взаємопов'язані, але й визначають один одного й за своїм змістом часом співпадають.

Виходячи із зазначеного, можна стверджувати, що мотиви злочинного діяння тісно пов'язані з особистістю як внутрішньою єдиною і складною системою стану, якостей та процесів. Тому вивчення взаємозв'язку мотивів злочинної діяльності й особистості злочинця $€$ однією з важливих задач соціально-психологічних і кримінологічних досліджень.

Таким чином, під час дослідження суб'єктивних ознак втягнення неповнолітнього у кримінальне правопорушення для кваліфікації діяння дорослого, а також вчинення кримінального правопорушення неповнолітньою особою самостійно чи разом з іншими співучасниками свого віку, дуже важливе значення має мотив і ціль. Не знаючи мотиву такого правопорушення, дуже важко, а інколи й неможливо встановити його причини й прийняти необхідні заходи до їх усунення, правильно кваліфікувати дії винної неповнолітньої особи й обґрунтовано призначити йому покарання. Тому слідчому під час визначення суб'єктивних ознак складу кримінального правопорушення неповнолітнього вкрай необхідно встановлювати ці дві підстави, що сприятиме застосуванню об'єктивності під час оцінки протиправних діянь цієї категорії громадян нашої держави.

\section{ЛITEPATУРА:}

1. Бабой А.М. Особливості втягнення неповнолітніх у злочинну діяльність. Підприємництво, господарство, право. 2019. № 12. С. 277-283.

2. Кримінальний кодекс України : Закон України від 05 квітня 2001 р. № 2341-III (у редакції від 16 січня 2020 р.) / Верховна Рада України. URL: https://zakon.rada.gov.ua/ laws/show/2341-14 (дата звернення: 08.02.2020).

3. Кримінальне право України. Загальна частина : підручник / за ред. М.I. Мельника, В.А. Клименка. Київ : Юридична думка, 2004. 328 с.

4. Лень В.В. Осудність у кримінальному праві і законодавстві : монографія. Дніпропетровськ : Дніпропетровськ держ. ун-т внутр. Справ ; Ліра ЛТД, 2008. 180 с.

5. Нежурбіда С.I. Етіологія злочину: теорії, аналіз, результат : монографія. Чернівці : Друк Арт, 2013. 432 с. 
6. Орел Ю.В. Кримінально-правова охорона нормальної діяльності органів та установ пенітенціарної служби України за законодавством Київської Русі. Форум права. 2014. № 1. С. 400-405.

7. Пионтковский А.А. Учение о преступлении по советскому уголовному праву. Москва, 1961. 401 C.

8. Савченко А.В. Кримінальна відповідальність за шахрайство в Україні та за кордоном: порівняльно-правове дослідження : монографія. Київ : Видавництво ТОВ «НВП» ІнтерсерBiC», 2013. 216 C.

9. Савченко А.В. Кримінальне право України. Загальна частина (у схематичних діаграмах) : посібник / за заг. ред. доц. В.В. Чернєя. Київ : Видавництво ТОВ «НВП «Інтерсервіс», 2013. 160 c.

10. Фесенко Є.В. Злочини проти здоров'я населення та системи заходів з його охорони : монографія. Київ : Атіка, 2004. 280 с. 